\title{
Islamic Faith-Based Content and Religious Social-media Motives
}

\author{
Khairil Anwar ${ }^{1}$ \\ Institut Agama Islam Negeri Palangka Raya, Palangka Raya, Indonesia \\ Abdul Mujib \\ Universitas Islam Negeri Syarif Hidayatullah, Jakarta, Indonesia
}

\begin{abstract}
The predominance and use of social media for sacred and secular purposes have made it imperative to understand the role of social media in people's religious motives and life. Therefore, grounded in gratification theory, the current study examines the impact of social media usage intensity, social media usage frequency, and religious appreciation in developing and strengthening different motives, i.e., ministering, spiritual enlightenment, religious information, relaxing entertainment, and well-being, among the followers of social media pages/accounts/sites for faith-based content. Following a quantitative research methodology, data were collected from the 562 followers of social media, i.e., Facebook, YouTube, Instagram, and Twitter. Data were analyzed using Structural Equation Modeling (SEM) in SmartPLS3 software. The results revealed that social media usage intensity and frequency positively influenced all five motives of individuals with a higher impact on individuals' motive of gaining religious information followed by spiritual enlightenment and wellbeing. Likewise, religious appreciation positively impacted all five motives of individuals to assess the faith-based content on social media pages/accounts/sites. However, the intensity of the impact varied from well-being, relaxing entertainment, ministering, religious information to spiritual enlightenment from the highest to lowest level, respectively. Moreover, the unique concept, theoretical and practical implications, and future research insights of the study are major advances to literature in the field.
\end{abstract}

Keywords: Social Media Usage Intensity; Spiritual Enlightenment; Religious Information; Relaxing Entertainment, Well-Being.

Nowadays, social media is used in every walk of life, including religious matters (Siles et al., 2021). Religious leaders all over the globe use social media as a universal channel to communicate with their followers (Buckley, Gainous, \& Wagner, 2021). Researchers also report the acceleration of social media for religious communications and shifting the individuals' worship behaviors since the last decade (Brubaker \& Haigh, 2017). After the religion's proliferation in social media, sharing one's thoughts, faith and engaging people on these media is very common today (Tsuria \& Yadlin-Segal, 2021). In addition, the affordability of social media technology helps

\footnotetext{
${ }^{1}$ Correspondent Author: A lecturer of Islamic Thought and Rector of Institut Agama Islam Negeri Palangka Raya, Central Kalimantan, Indonesia E-Mail: khairil.anwar@iain-palangkaraya.ac.id
} 
religious scholars communicate their message to a large audience and persuade them to participate in religious matters and perform their rituals (Willis et al., 2020; Akrim \& Dalle, 2021).

Moreover, research reveals a dire need to understand the gratification received from the excessive use of social media to spread religious content among various communities all over the globe (Brubaker \& Haigh, 2017; Buckley et al., 2021; Damgaci \& Aydin, 2018). Hence, extending the body of literature regarding social media to spread religious knowledge, the current study explores various motives of individuals while accessing and sharing faith-based content on social media pages/accounts/sites. In connection to that, the current study examined the impact of usage intensity and frequency of social media in determining the various motives among social media users. Additionally, the impact of religious appreciation on different religious, social media motives, i.e., ministering, spiritual enlightenment, well-being, relaxing entertainment, and faithbased information, has also been empirically examined to provide evidence from a diverse cultural context of Indonesia with a majority Muslim population living alongside multiple religious minorities.

Ministering reflects the spread of religious believes and messages that encourage, uplift, and/or inspire others while actively reaching out to them (Yoo \& You, 2021) besides fulfilling the emotional and spiritual needs by facilitating and helping others restore faith and religious beliefs among individuals (Goatley, 2020). Hence, ministering strengthens the religious and spiritual believes among individuals (Radstake, 2021). At the same time, spiritual enlightenment depicts individuals' efforts to enlighten themselves with the available religious content and enhance their spiritual knowledge (Anorboevich, 2021). Spiritual enlightenment reflects someone's efforts to extract religious information and guidelines to uplift their existing positions and enhance their growth and progress in life (Morgan, 2019). Based on the immense importance of spiritual enlightenment in developing and strengthening religious believes among individuals Brubaker \& Haigh (2017) highlighted that in today's digital media age, the impact of social media use for religious teachings in creating and strengthening spiritual enlightenment among followers should be examined. Therefore, responding to this call, the current study investigates the impact of using social media intensity, frequency, and religious appreciation in determining the motive of ministering and spiritual enlightenment among followers.

Simultaneously, religious information is the third most important factor that has been considered an outcome of accessing faith-based content on social media pages/accounts/sites with variable intensity and frequency. Religious information reflects the information available on various Social Networking Sites (SNSs) related to the religious guidelines, rules, regulations, ritual details, and a complete code of dos and don'ts in light of examples (Almobarraz, 2021). This further shows that one key goal of using social media is to gain religious information that someone can utilize in every walk of life as a guideline provided by their religious scholars. The same has been empirically tested to derive valuable insights.

In addition, another important construct, i.e., relaxing entertainment, has been considered an outcome of using social media for religious/spiritual insights and religious appreciation. Relaxing entertainment reflects the use of any activity and/or information to gain peace of mind and enjoy that activity (Khan, 2017). The latest research shows that individuals use/follow various social media pages/accounts/sites to assess the religious teachings that make them relax ( $\mathrm{Ab}$ Rahman et al., 2020). The current study extends the existing literature by examining the impact of social media usage intensity and frequency and religious appreciation to determine relaxing entertainment among individuals.

Finally, the fifth motive considered in the current study is well-being. Well-being has been conceptualized as a combination of feeling good and functioning well (Samad, Nilashi, \& Ibrahim, 
2019). The literature depicts the positive influence of religious teachings on individuals' well-being (Fortuin, 2021; Wilt, Stauner, \& Exline, 2017). In the current study, the impact of individuals' uses of social media with varying intensity and frequency to gain religious information and interact with religious scholars to receive guidelines regarding various matters on their well-being has been uniquely assessed. Such integrated investigations are scarce in religious and information science literature.

Furthermore, the current study utilized the uses and gratification theory, which suggests that most individuals who use social media to access religious information and spiritual insights want to gratify their specific needs (Eginli \& Tas, 2018). Also, the use of social media is economical and purposefully meets individuals' spiritual needs and desires by providing abundant religious content and facilitating direct interactions with religious scholars (Latepo, Suharto, \& Nurdin, 2021). Hence, grounded in the uses and gratification theory, utilizing the religious information given on social media and actively communicating with the religious leaders create various motivations among the followers. Therefore, the current study aims to answer the following research questions.

a. To what extent is social media usage intensity helpful in generating an individual's religious motives, i.e., ministering, spiritual enlightenment, faith-based information, relaxing entertainment, and well-being?

b. To what extent is social media usage frequency helpful in generating an individual's religious motives, i.e., ministering, spiritual enlightenment, faith-based information, relaxing entertainment, and well-being?

c. To what extent is religious appreciation helpful in generating an individual's religious motives, i.e., ministering, spiritual enlightenment, faith-based information, relaxing entertainment, and well-being?

\section{Literature Review}

\section{Social Media Usage Intensity, Frequency and Individuals' Religious Motives}

Different cultures have different meanings for religion. Following Williams (1996), religion is both an ideology which is "an organizing principle for the reordering of society [...] clothed in the universalist language of God's will and transcendent justice", and a culture "that is, practical understandings, conventions, and ways of life and experience " (p. 374). In all parts of the world, the use of social media to spread faith-based content or religious information is increasing (Siles et al., 2021). Besides, previously it has been stated that faith-based content available on social media pages/accounts/sites can be shared by the users/followers to those who are either ignorant are not in a better position to access the faith-based material and content otherwise (Radstake, 2021). Likewise, Goatley (2020) asserted that those who follow religious content on social media feel satisfaction after sharing such content with their fellows and use social media to achieve the motive of ministering originates from the sharing or expressing the information of someone's interest that they want to express and share with others (Papacharissi \& Mendelson, 2011).

Research shows the importance of various social media channels, i.e., Facebook, for preaching, hence reflecting the importance of using various social media pages/accounts/sites to 
share one's believes, messages, and religious teachings to others so that they find the right ways to proceed in their life with the right decisions with the help of religious guidelines (Huda \& Nur, 2021). Extending the existing literature and grounded in the gratification theory, followers of religious social media pages/accounts/sites do not merely share interesting information with others. Still, their main motive is establishing a relationship with others having the same faith (Aminullah et al., 2021). In other words, they approach and uplift others to engage them in faith-based conversations via uploading faith-based messages and content.

Spiritual enlightenment reflects a person's urge to enhance his/her knowledge with the help of available religious content on various platforms (Anorboevich, 2021). Previously various factors, including psychological individualism (Stein, 2019) and religious guidelines (Howe \& Parker, 2014), have been considered determinants and facilitators of individuals' spiritual enlightenment. The current study considers that the religious content in the form of guidelines and spiritual teachings available on social media helps individuals enlighten themselves with their religion. Research shows that social media channels are affordable and have abundant information related to different matters of life (Wang \& Qiao, 2020). Likewise, numerous religious scholars communicate with their followers on different social media channels (Buckley et al., 2021). Hence, it is very convenient for those who want to enhance their knowledge regarding religious guidelines and teachings (Almobarraz, 2021; Huda \& Nur, 2021). Therefore, people repeatedly visit different social media pages/accounts/sites to gain religious information.

The literature also reveals that many people visit different sites pages accounts on social media to relax and entertain themselves (Stollfub, 2020). In connection to that, Brubaker and Haigh (2017) asserted that the people who follow religious pages on Facebook do so to find relaxation and entertainment purposes. Along the same lines, the current study proposes that utilizing the available guidelines material and information on social media pages/accounts/sites, individuals tend to relax and entertain themselves by remaining within the boundaries prescribed in their religion. This further provides them a sense of contentment and peace of mind that whatever they are doing is right and is suggested by their supreme Lord for their goodwill and betterment.

In addition, well-being has been defined in multiple contexts and multiple ways; however, in the context of the current study, the current study considered well-being as the presence of positive mood and emotions arising based on the religious content available on social media pages/accounts/sites, which are easily assessable to individuals. Hence, this study proposed that the social media usage intensity and frequency of use of faith-based content helps users develop positive moods and emotions.

Moreover, researchers have demonstrated the importance of personal disclosures, frequency of social media usage, and social connectedness in enhancing the individuals' gratification level (Ledbetter et al., 2011; Tsay-Vogel, 2016). Extending the existing body of literature and applying the uses and gratification theory, the current study reveals the importance of faith-based content available on various social media pages/accounts/sites to gratify several motives of followers. Hence it is hypothesized that;

\section{Religious Appreciation and Individuals’ Religious Motives}

Religious appreciation presents the religious lifestyle to spend one's life according to the teachings and guidelines of their religion (Bullik \& Stacke, 2018). In the current study, religious lifestyle has been considered as spending one's life according to the guidelines and teaching provided by Islam (Syarif, 2020). Besides, religious appreciations encourage individuals to indulge in positive behavior such as helping others, offering prayers, keeping themselves neat and clean, 
and taking care of others (Askeland, Espedal, \& Sirris, 2019). In addition, research also reveals the importance of sharing religious content to uplift others participation in religious activities (Radstake, 2021), enhance spiritual enlightenment (Stein, 2019), gain religious information (Brubaker \& Haigh, 2017), relax and entertain themselves (Stollfub, 2020) and enhance well-being (Fortuin, 2021). Therefore, established on the uses and gratification theory, the current study extends the existing literature and examines the impact of Islamic religious appreciation via accessing the faith-based content available on social media pages/accounts/sites to gratify individuals' motives. Hence, it is proposed that;

\section{Theoretical Framework of the Study}

\section{Figure 1}

Theoretical Framework of the Study

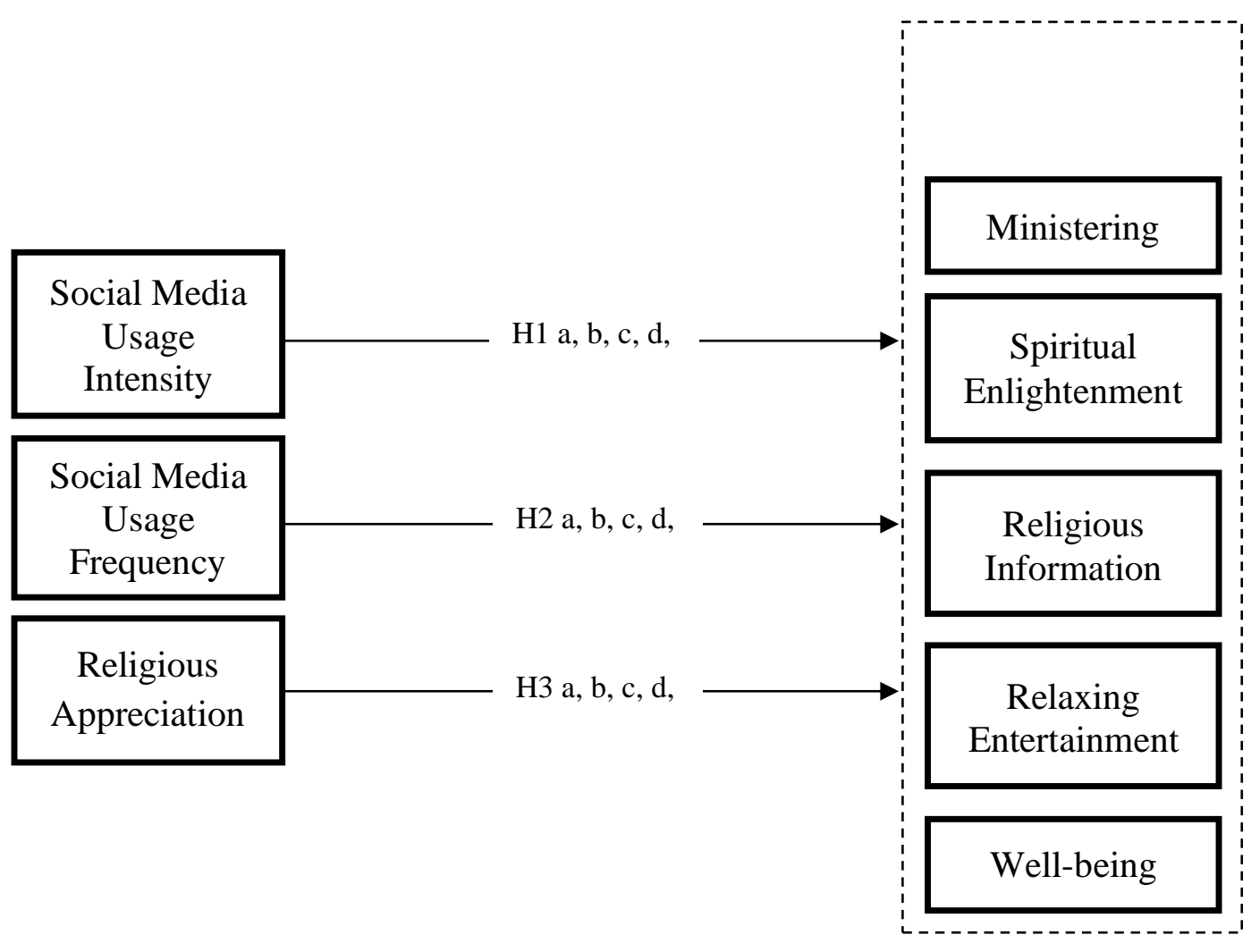

\section{Hypotheses of the Study}

H1: Social Media usage intensity positively influences individuals' motives for a) ministering, b) spiritual enlightenment, c) faith-based information, d) relaxing entertainment, and f) well-being.

H2: Social Media usage frequency positively influences individuals' motives for a) ministering, b) spiritual enlightenment, c) faith-based information, d) relaxing entertainment, and f) well-being. 
H3: Religious appreciation positively influences individuals' motives for a) ministering, b) spiritual enlightenment, c) faith-based information, d) relaxing entertainment, and f) well-being.

\section{Methodology}

The current study framework was empirically tested using a quantitative research approach where an online survey was conducted to collect data from the followers of various religious, social media page/accounts/sites, i.e., Facebook, YouTube, Instagram, and Twitter in Indonesia. Per the statistics, by January 2021, there were 170 million active social media users in Indonesia, ranking third after China and India in the Asia Pacific region (Saputri, Saputri, \& Yumarni, 2021). In Indonesia, $86.7 \%$ practice Islam, making it the most followed religion in Indonesia (Fauzi \& Asri, 2021). In addition, per 2021 statistics, in Indonesia, there are 136.96 million users of Facebook, 132 million users of YouTube, 87.8 million users of Instagram, and 15.7 million users of Twitter. These statistics show that most Indonesian people use/follow various social media accounts/pages/sites. Similarly, research also shows that most Indonesians follow various religious pages/sites (Syarif, 2020). Hence, the choice of study context is timely to examine the impact of social media usage intensity and frequency in determining and creating the individuals' motives for a) ministering, b) spiritual enlightenment, c) faith-based information, d) relaxing entertainment, and f) well-being for the religious faith content available on social media accounts/pages/sites to devise valuable policy insights.

To collect data, the current study's authors identified active followers of religious social media pages/accounts/sites and sent them a message with a cover letter with a complete description of the reason for contacting them on January 10, 2021. Also, the essential details related to the reason for conducting this research were included in that letter. The social media followers were briefed about the researchers' intentions and were ensured about the anonymity of their responses if they agreed to participate in the survey, which was in Indonesian. Approximately 1200 active followers of various religious social media pages/accounts/sites were approached, of which 690 responded and showed the willingness to participate in the survey. After taking consent from the respondent, a questionnaire consisting of two parts was sent to them. The first part consisted of details related to the demographic characteristics of the respondents and the second part consisted of 50-items of the eight study constructs. All the items were marked as important to avoid missing values. After three months of sending the questionnaire, which continued until April 15, 2021, 595 questionnaires were returned, which were screened before proceeding towards the analysis part. The careful screening revealed that 33 questionnaires had unengaged patterns, which were excluded from the analysis. Hence, a total of 562 responses generating a response rate of $46.85 \%$ were included in the further analysis.

\section{Measures of the Study}

To examine the impact of social media usage intensity, frequency, and religious appreciation on various individual motives, a 50-item questionnaire comprising items adapted from existing studies was developed (See Table 1). Social media usage intensity was measured with a six-item scale by Ellison, Steinfield, and Lampe (2007), reflecting the connectivity SNSs create while users assess the religious communities and faith-based content. The sample items include "Spiritual content in part of my everyday routine," "I feel I am part of a religious, social media community of faith," and "I would feel sorry if social media accounts, i.e., Facebook, Twitter, Instagram, and YouTube stop sharing religious or faith-based content." Responses were recorded 
on a 7-point Likert Scale " $1=$ strongly disagree to $7=$ strongly agree." Social media usage frequency was measured with a four-item scale adapted from Brubaker and Haigh (2017). The items measured the frequency of posting, liking, commenting, and sharing religious content on various social media channels, i.e., Facebook, Twitter, Instagram, and YouTube. Responses were measured on a 7-point Likert scale ranging from $1=$ never to $7=$ every time $\log$ on. Religious appreciation was measured with an eleven-item scale adapted from Mustapa et al. (2020). The sample items include "religious teachings bring positive changes in my life." Responses were recorded on a 7-point Likert Scale " $1=$ strongly disagree to $7=$ strongly agree." The gratification scale that Brubaker and Haigh (2017) developed was used to measure a) ministering with twelve items (sample items include "I engage in religious content on social media to encourage/assist those who are in need of spiritual support" and "I engage in religious content on social media to uplift others"), b) spiritual enlightenment with six-items (sample items including "I engage in religious content on social media because it facilitates my spiritual connection with God/ Allah/deity, etc."), c) religious information with three-items items (sample items include "I engage in religious content on social media to access information about religious services, activities, or event"), d) relaxing entertainment with threeitems (sample items include "I engage in religious content on social media because it allows me to unwind" and "I engage in religious content on social media because it makes it entertaining"). Finally, the fifth motive, well-being, was measured with the WHO five-item scale adapted from Bech et al. (2003). All the items for motives were measured on a 7-point Likert scale ranging from "1 = not at all to 7 = exactly."

\section{Demographic Characteristics of the Participants}

\section{Table 1}

\begin{tabular}{|c|c|c|c|}
\hline \multicolumn{2}{|c|}{ Variables } & \multirow{2}{*}{$\begin{array}{l}\text { Number }(\mathrm{N}=536) \\
293\end{array}$} & \multirow{2}{*}{$\begin{array}{r}\% \text { age } \\
52.1 \%\end{array}$} \\
\hline Gender & Male & & \\
\hline & Female & 269 & $47.9 \% \%$ \\
\hline \multirow[t]{2}{*}{ Marital status } & Married & 240 & $42.7 \%$ \\
\hline & Unmarried & 322 & $57.3 \%$ \\
\hline \multirow[t]{4}{*}{ Age } & $18-25$ years & 128 & $22.8 \%$ \\
\hline & 26-35 years & 147 & $26.1 \%$ \\
\hline & $36-45$ years & 168 & $29.9 \%$ \\
\hline & 45 and above & 119 & $21.2 \%$ \\
\hline \multirow[t]{3}{*}{ Education } & Undergraduate & 170 & $30.2 \%$ \\
\hline & Graduate & 277 & $49.3 \%$ \\
\hline & Post-graduate & 115 & $20.5 \%$ \\
\hline \multirow[t]{4}{*}{ Occupation } & Student & 127 & $22.6 \%$ \\
\hline & Employees & 153 & $27.2 \%$ \\
\hline & Self-employed & 159 & $28.3 \%$ \\
\hline & Others & 123 & $21.9 \%$ \\
\hline
\end{tabular}


Table 1 shows a detailed summary of sample characteristics. There were 293 males and 269 females, and respondents were symmetrically distributed among different age groups. Respondents belonged to different age groups depicting a diversified sample characteristic. In contrast, in terms of education, almost half of the respondents $(49.3 \%)$ were graduates.

\section{Data Analysis and Results}

\section{Measurement Model Assessment}

Smart PLS 3 software was used to assess the measurement model. In the beginning, simulation analysis was performed to check the impact of respondents' demographic characteristics on the exogenous construct. The results revealed the insignificant impact of all the demographic characteristics of the respondents on dependent constructs; therefore, none of the respondent's demographic characteristics was controlled during the analysis. Besides establishing the constructs' reliability, Cronbach's alpha (CA), Composite Reliability (CR), and Average Variance Extracted (AVE) were calculated (Hair et al., 2010; Mansoor \& Paul, 2021). The measurement model results revealed that factor loading of all the items of study constructs was above 0.70 . Likewise, CA, CR, and AVE values were $>0.70,>.70$, and $>0.50$ simultaneously, which were above the threshold values that scholars have recommended (Hair et al., 2010; Henseler, Ringle, \& Sarstedt, 2015; Mansoor, 2021; Sarstedt, Ringle, \& Hair, 2017). Hence, constructs' reliability was established, as shown in Table 2. 


\section{Table 2}

Factor loadings, reliability, and validity

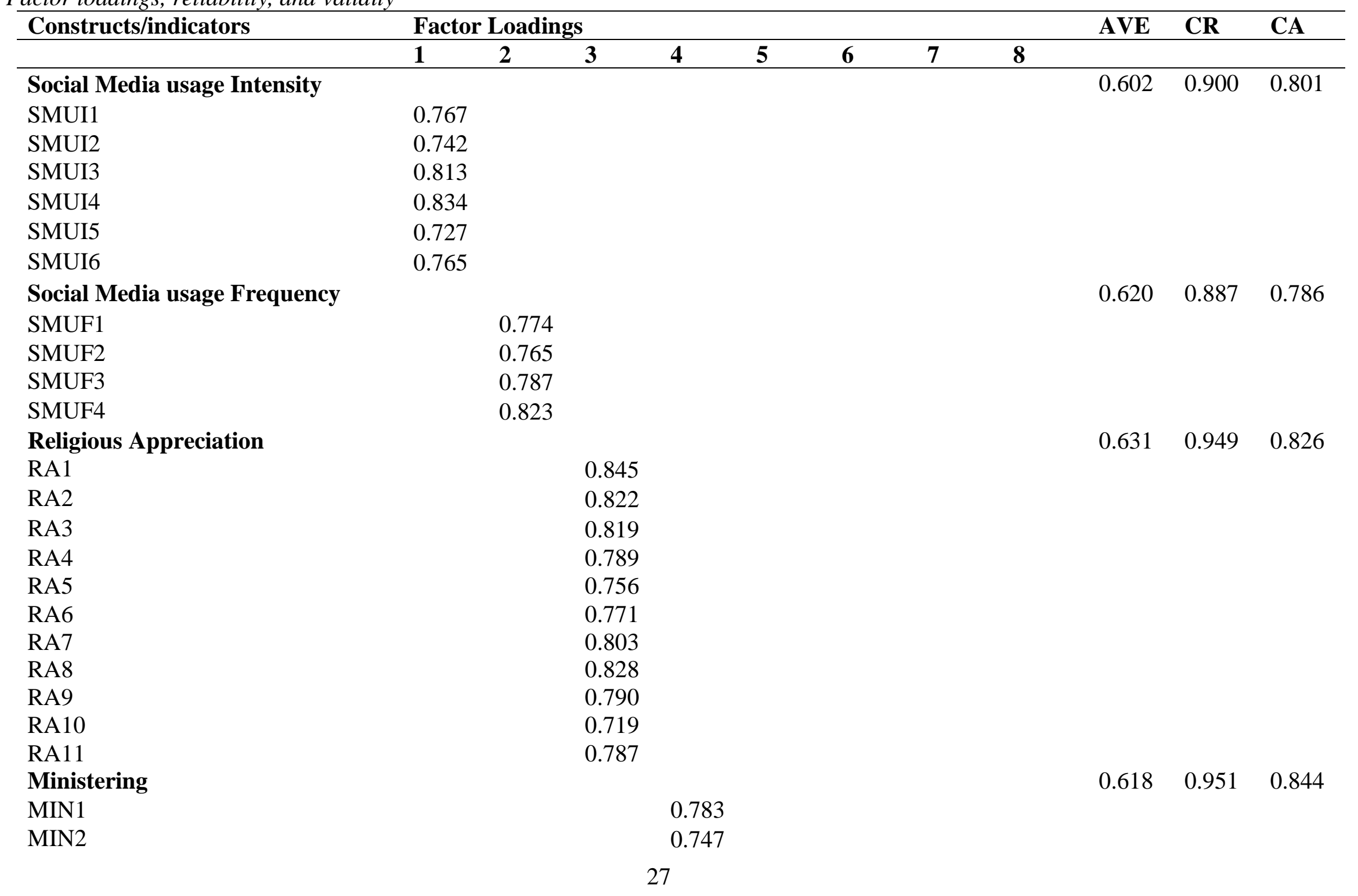




$\begin{array}{ll}\text { MIN3 } & 0.769 \\ \text { MIN4 } & 0.763 \\ \text { MIN5 } & 0.764 \\ \text { MIN6 } & 0.820 \\ \text { MIN7 } & 0.786 \\ \text { MIN8 } & 0.760 \\ \text { MIN9 } & 0.805 \\ \text { MIN10 } & 0.879 \\ \text { MIN11 } & 0.811 \\ \text { MIN12 } & 0.734\end{array}$

Spiritual Enlightenment

SE1

SE2

SE3

SE4

SE5

SE6

Religious Information

RI1

RI2

RI3

Relaxing Entertainment

RE1

RE2

RE3

Well-being

WB1

WB2

WB3

WB4

WB5
0.763
0.764
0.786
0.760
0.805
0.811
0.734
0.787
0.741
0.752
0.736
0.802
0.809

$\begin{array}{lll}0.596 & 0.898 & 0791\end{array}$

$\begin{array}{lll}0.651 & 0.848 & 0.779\end{array}$

0.766

0.792

0.859

$\begin{array}{lll}0.630 & 0.836 & 0.760\end{array}$

0.827

0.791

0.762

$\begin{array}{lll}0.605 & 0.884 & 0.782\end{array}$

0.746

0.838

0.727

0.760

0.811 
In addition, to establish the constructs' discriminant validity, Heterotrait-Monotrait Ratio and Fornell-Larcker-Criterion were accessed (Henseler, Ringle, \& Sinkovics, 2009; Noor, Mansoor, \& Rabbani, 2021). The Fornell-Larcker Criterion suggests that "the square root of each construct's AVE should be higher than its correlation with another construct" (Fornell \& Larcker, 1981; Henseler et al., 2015; Mansoor \& Noor, 2019). At the same time, researchers suggest that values of the HTMT ratio should be $<0.90$. The values of the HTMT ratio and Fornell-Larcker were per the recommended range, hence establishing the constructs' discriminate validity (see Table 3 and Figure 2).

\section{Table 3}

Heterotrait-Monotrait Ratio

\begin{tabular}{lcccccccccc}
\hline Constructs & Mean & STD. & 1 & 2 & 3 & 4 & 5 & 6 & 7 & 8 \\
\hline SMUI & 5.46 & 1.23 & $\mathbf{0 . 7 7 5}$ & & & & & & & \\
SMUF & 5.51 & 1.20 & 0.627 & $\mathbf{0 . 7 8 7}$ & & & & & & \\
RA & 6.04 & 0.92 & 0.588 & 0.564 & $\mathbf{0 . 7 9 4}$ & & & & & \\
MIN & 5.73 & 1.09 & 0.579 & 0.545 & 0.498 & $\mathbf{0 . 7 8 6}$ & & & & \\
SE & 5.90 & 1.02 & 0.520 & 0.490 & 0.442 & 0.506 & $\mathbf{0 . 7 7 2}$ & & & \\
RI & 5.66 & 1.14 & 0.478 & 0.493 & 0.654 & 0.510 & 0.339 & $\mathbf{0 . 8 0 6}$ & & \\
RE & 5.69 & 1.10 & 0.434 & 0.513 & 0.630 & 0.681 & 0.502 & 0.500 & $\mathbf{0 . 7 9 3}$ & \\
WB & 5.83 & 1.05 & 0.390 & 0.566 & 0.567 & 0.632 & 0.526 & 0.607 & 0.589 & $\mathbf{0 . 7 7 7}$ \\
\hline
\end{tabular}

Notes: The square roots of AVEs of the constructs are shown in bold in diagonal and show the discriminant validity of the constructs. SMUI= Social Media Usage Intensity; SMUF= Social Media Usage Frequency; RA= Religious Appreciation; MIN= Ministering; SE= Spiritual Enlightenment; RI= Religious Information; RE= Relaxing Entertainment; WB= Well-being.

\section{Figure 2}

Measurement Model

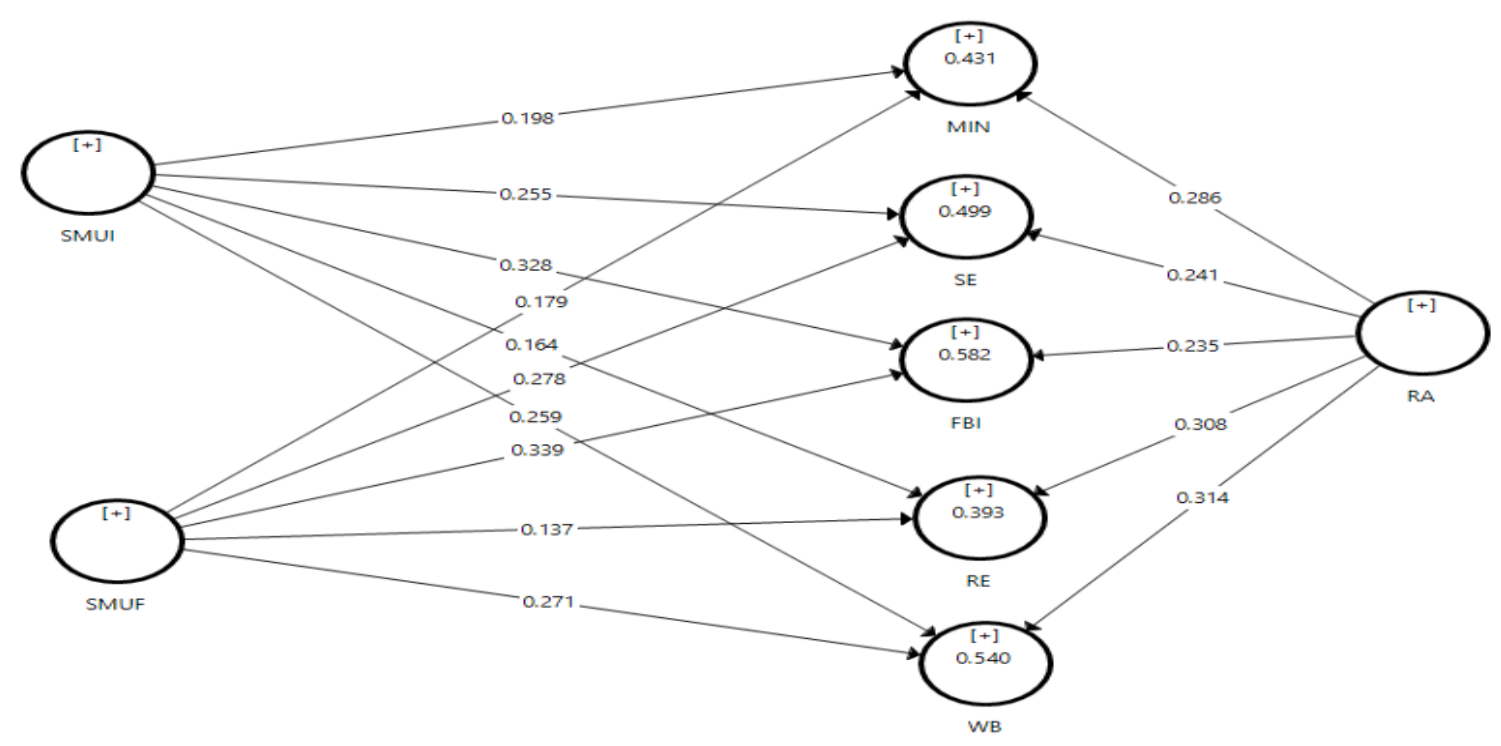




\section{Structural Model Assessment}

To test the study hypothesis structural model, the bootstrapping technique applied 500 subsamples in small PS3 software (Mansoor, 2021; Sarstedt et al., 2017). To report the significance of the proposed relationship and the impact size, $\beta$-coefficient, $\mathrm{p}$-value, and t-value were used. In addition, overall theoretical frameworks' fitness was assessed using the Coefficient of Determination (R2). The results showed a $43.1 \%$ variance in ministering based on the social media usage intensity, frequency, and religious appreciation. At the same time, $49.9 \%$ variance was found in spiritual enlightenment due to the social media intensity, frequency, and religious appreciation. The variance observed in religious information, relaxing entertainment, and well-being was 58.2\%, $39.3 \%$, and $54.0 \%$, respectively, due to all independent variables. All these results depict the good fitness of the model proposed in the current study.

\section{Hypothesis Testing}

Results showed positive and significant influence of social media usage intensity to access the religious content on ministering $(\beta=.198 * *, t=4.300)$, spiritual enlightenment $(\beta=.252 * * *$, $\mathrm{t}=5.006)$, religious information $(\beta=.328 * * *, t=6.780)$, relaxing entertainment $(\beta=.164 * *, t=$ 3.260), and well-being $(\beta=.259 * * *, t=5.075)$. Besides, the impact of social media usage intensity was highest on religious information, followed by well-being and spiritual enlightenment. The results also showed the positive impact of social media usage frequency to access religious content in creating ministering $(\beta=.179 * *, t=3.489)$, spiritual enlightenment $(\beta=.278 * * *, t=5.708)$, religious information $\left(\beta=.339^{* * *}, \mathrm{t}=7.420\right)$, relaxing entertainment $(\beta=.137 * *, t=2.977)$, and well-being $\left(\beta=.271^{* * *}, \mathrm{t}=5.425\right)$ among the users of social media. These results were similar to the above findings, depicting the highest impact of social media usage frequency on religious information followed by spiritual enlightenment and well-being. In addition, the impact of social media usage frequency was also significant in creating relaxing entertainment and ministering among the followers, revealing the importance of faith-based content available on various social media pages/sites/accounts in developing various motives among followers. Results also showed the positive association of religious appreciation with ministering $\left(\beta=.286^{* * *}, \mathrm{t}=5.896\right)$, spiritual enlightenment $\left(B=.241^{* * *}, \mathrm{t}=4.953\right)$, religious information $\left(B=.235^{* * *}, \mathrm{t}=4.862\right)$, relaxing entertainment $\left(B=.308^{* * *}, t=6.214\right)$, and well-being $\left(B=.314^{* * *}, t=6.320\right)$. However, the strength of the relationship was quite different from that of previously mentioned relationships. For instance, religious appreciation had the highest impact on followers' well-being, followed by relaxing entertainment and ministering. Hence, the results supported all the study hypotheses, as shown in Table 4. Moreover, the significance levels of all the hypothesized relationships are given

in figure 3, which depicts that all the t-values are above the threshold value of $>1.96$. Hence all the hypotheses are supported by the study results. 


\section{Table 4}

Hypothesis Testing Results

\begin{tabular}{llcccc}
\hline & Hypotheses & Std. Beta & $t$-Value & $p$-values & Supported \\
\hline $\mathrm{H}_{1 \mathrm{a}}$ & SMUI $\rightarrow$ MIN & 0.198 & 4.300 & 0.005 & Yes \\
$\mathrm{H}_{1 \mathrm{~b}}$ & SMUI $\rightarrow \mathrm{SE}$ & 0.255 & 5.006 & 0.000 & Yes \\
$\mathrm{H}_{1 \mathrm{c}}$ & SMUI $\rightarrow \mathrm{RI}$ & 0.328 & 6.780 & 0.000 & Yes \\
$\mathrm{H}_{1 \mathrm{~d}}$ & SMUI $\rightarrow \mathrm{RE}$ & 0.164 & 3.260 & 0.010 & Yes \\
$\mathrm{H}_{1 \mathrm{e}}$ & SMUI $\rightarrow$ WB & 0.259 & 5.075 & 0.000 & Yes \\
$\mathrm{H}_{2 \mathrm{a}}$ & SMUF $\rightarrow$ MIN & 0.179 & 3.489 & 0.009 & Yes \\
$\mathrm{H}_{2 \mathrm{~b}}$ & SMUF $\rightarrow$ SE & 0.278 & 5.708 & 0.000 & Yes \\
$\mathrm{H}_{2 \mathrm{c}}$ & SMUF $\rightarrow$ RI & 0.339 & 7.420 & 0.000 & Yes \\
$\mathrm{H}_{2 \mathrm{~d}}$ & SMUF $\rightarrow$ RE & 0.137 & 2.977 & 0.013 & Yes \\
$\mathrm{H}_{2 \mathrm{e}}$ & SMUF $\rightarrow$ WB & 0.271 & 5.425 & 0.000 & Yes \\
$\mathrm{H}_{3 \mathrm{a}}$ & RA $\rightarrow$ MIN & 0.286 & 5.896 & 0.000 & Yes \\
$\mathrm{H}_{3 \mathrm{~b}}$ & RA $\rightarrow \mathrm{SE}$ & 0.241 & 4.953 & 0.003 & Yes \\
$\mathrm{H}_{3 \mathrm{c}}$ & RA $\rightarrow \mathrm{RI}$ & 0.235 & 4.862 & 0.003 & Yes \\
$\mathrm{H}_{3 \mathrm{~d}}$ & RA $\rightarrow \mathrm{RE}$ & 0.308 & 6.214 & 0.000 & Yes \\
$\mathrm{H}_{3 \mathrm{e}}$ & RA $\rightarrow$ WB & 0.314 & 6.320 & 0.000 & Yes \\
\hline
\end{tabular}

Figure 3

Structural Model

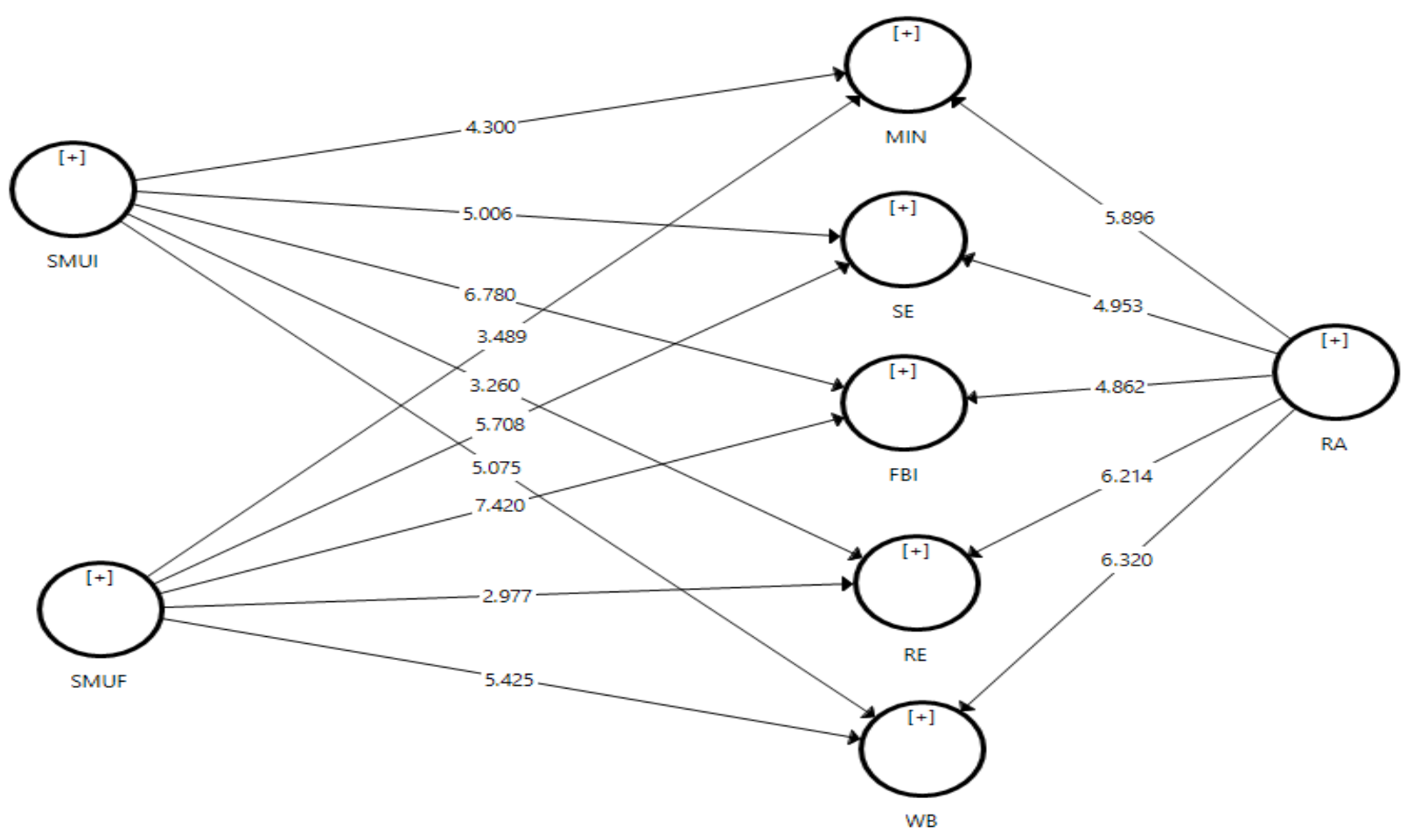




\section{Discussion and Conclusion}

The current study examined the social media followers' gratifications for engaging in faithbased content on different social media pages/accounts/sites. The results revealed that social media usage intensity and frequency positively impacted the users'/followers' spiritual and temporal needs from ministering to their well-being. The results showed the positive impact of social media usage intensity and frequency on ministering, reflecting the followers' use of faith-based content and belief to uplift the religious messages to others. These results align with the previous studies, which showed the importance of using Facebook for uplifting these religious messages to the masses (Brubaker \& Haigh, 2017). Besides, the results revealed that gratification of faith-based content satisfies the religious followers' needs beyond the typical SNS users in various ways. This further shows that offering emotional and spiritual comfort to others satisfies individuals and develops a sense of gratification; as a result, they continue their practice of ministering via utilizing different social media channels.

The results also showed the positive impact of social media using intensity and frequency in enhancing the individual motive of spiritual enlightenment. These results reflect that in addition to guiding others related to religious matters and sharing the religious-based content and teachings, the people also want to spiritually enlighten themselves by reading the religious scholars' posts and messages. Hence, they tend to enhance their own understanding of religious matters using social media to apply it in their life matters (Anorboevich, 2021; Howe \& Parker, 2014). Moreover, the results also showed a positive association between social media usage intensity and frequency and the individuals' motivation to gain religious information. This further reflects the ease of getting spiritual and faith-based information using social media frequently without any barriers and difficulties (Siles et al., 2021).

In addition, individuals revealed the importance of using social media intensely and frequently for relaxing and entertainment purposes. This further shows that social media provides leverage to the individuals who want to relax, unwind and entertain themselves (Stollfub, 2020). This entertainment can be related to the satisfaction gained by individuals after reading and applying the faith-based content (Brubaker \& Haigh, 2017). In other words, results show that social media channels represent an expressive medium where followers can spread religious information to others, express their beliefs, and provide spiritual support to others and receive the same from others, including entertainment and relaxation. Additionally, social media channels provide a platform for individuals to communicate with the masses from different regions and listen to renowned and influential religious scholars without being physically present there.

The results also demonstrated the importance of faith-based content on social media channels and the intensity and frequency of social media usage on individuals' motivation to attain well-being. It further shows that the individuals who actively participate in religious-based conversations on social media and intensely use the media to communicate with others feel more energetic and healthier with good moods and positive emotions. Hence, involving in religiousbased activities utilizing social media enhances the well-being of the individuals and further motivates them to spread that positivity. Furthermore, the results also revealed the importance of religious appreciation in developing and strengthening the various motives among the individuals who use social media channels. This reflects that the individuals who appreciate the importance of religion in their life and consider their faith as a part of their success and believes in destiny involve themselves more in religious conversations, sharing faith-based content, enlightening themselves with the religious teachings and guidelines, gaining more information about the religion, feel 
relaxation and entertainment while practicing religious rituals and sharing the religious messages to others. Finally, religious appreciation strengthens their well-being, and they feel satisfied and contented in their life.

\section{Theoretical Implications}

The current study offers various theoretical advances in the existing body of research. First, utilizing the gratification theory, the current study suggested a consolidated model of driving five different individual motives based on faith-based content available on social media pages/accounts/sites. Second, the current study uniquely presented the impact size of social media usage intensity and social media usage frequency in creating and enhancing the motives of ministering, spiritual enlightenment, religious information, relaxing entertainment, and well-being with a varying intensity which has not been previously examined and presented in a conical consolidated form. Third, the current study has incorporated the individuals' motives of guiding and helping others in the form of ministering and fulfilling their own needs of spiritual enlightenment, gathering religious information, relaxing and entertaining themselves, and attaining well-being. Fourth, in contrast to previous studies, which have primarily examined the use of one or two digital media channels, i.e., Facebook, to excess the various individual motives (Brubaker \& Haigh, 2017; Tanta, Mihovilović, \& Sablić, 2014), the current study has considered four different social media channels including Facebook, YouTube, Instagram, and Twitter. Hence, the results-driven from the current study are not based on a single social media platform but are the views of individuals using various social media platforms. Finally, the current study was conducted in Indonesian contacts, a Muslim-populated country among the major social media users in the Asia Pacific region ( Saputri, Saputri, \& Yumarni, 2021). Hence it is fascinating to find out the social media users' interest in religion and the use of social media pages/accounts/sites for religious teachings and enhancing people's well-being.

\section{Practical Implications}

The current study's findings can be valuable for policymakers, government bodies, and religious scholars to derive valuable insights. First, based on the significance of various religious, social media pages/accounts/sites in developing and strengthening the numerous motives among the individuals, the government bodies can utilize these religious networks to communicate with the masses and persuade them to follow certain rules and regulations which are for the benefits of the countries under the religious guidelines and teachings. Second, social media networks can also attract youth to come and participate in religious conversations and share the faith-based contest with others rather than wasting time on different gaming websites. Third, because Islam is a balanced religion that provides a complete code of conduct for people of all ages and genders, these teachings and guidelines can be utilized to enhance people's moral values and discourage them from criminal acts. Finally, by utilizing the various social media channels, religious scholars can attract individuals to practice the religious rituals stay away from bad deeds, help others and strengthen the economy. 


\section{Limitations of the Study}

In addition to numerous strengths, there are a few limitations of the current study that can be addressed in the future to extract valuable insights. First, the current study has examined the impact of social media usage intensity, frequency, and religious appreciation on individual motivations who identify themselves as Muslims and a part of the Islamic religion. In contrast, more diverse religious populations can be explored in the future to see the differences in their gratifications along with differences in impact size of social media usage intensity, frequency, and religious appreciations on the given individual motives. Second, the current study has examined the combined impact of samples gathered from different social media channels, Facebook, YouTube, Instagram, and Twitter, to check the individuals' motives they drive from social media use. In contrast, a comparison can be conducted among the users of different social media channels to see the predictive differences in their motives. Third, the current study only examined the direct impact of the social media usage intensity, frequency, and religious appreciation on five different individual motives. Besides the future studies can examine the underlying mechanisms involved in these relationships. Finally, the contingent impact of age and gender in these relationships can be explored in the future.

\section{References}

Ab Rahman, Z., Kashim, M., AY, M. N., Saari, C. Z., Hasan, A. Z., Ridzuan, A. R., . . AR, N. R. (2020). Critical review of religion in coping against the COVID-19 pandemic by former COVID-19 Muslim patients in Malaysia. International Journal of Critical Reviews, 7(5), 1145-1154. https://oarep.usim.edu.my/jspui/handle/123456789/6381

Akrim, A., \& Dalle, J. (2021). Mobile Phone and Family Happiness, Mediating Role of Marital Communication: An Attachment Theory Perspective. International Journal of Interactive Mobile Technologies (iJIM), 15(21), 107-118. https://doi.org/10.3991/ijim.v15i21.17811

Almobarraz, A. (2021). Investigating the seeking behavior for religious information in social media. In Research anthology on religious impacts on society (pp. 765-779). IGI Global. DOI: 10.4018/978-1-7998-3435-9.ch039

Aminullah, A. M., Ismaya, I., Syahdan, S., Ridwan, M. M., Jamaluddin, N., Elihami, E., \& Musdalifah, M. (2021). Pengembangan koleksi digital dalam Membangun Perpustakaan Digital di Perpustakaan Universitas Islam Negeri Alauddin Makassar [Development of digital collection in building a digital library in the Library of Alauddin Makassar State Islamic University]. EduPsyCouns: Journal of Education, Psychology and Counseling, 3(1), 58-68. https://ummaspul.e-journal.id/Edupsycouns/article/view/1100

Anorboevich, R. A. (2021). Principles of organizing the spiritual-enlightenment activities of future teachers. ACADEMICIA: An International Multidisciplinary Research Journal, 11(9), 400-407. 10.5958/2249-7137.2021.01930.3

Askeland, H., Espedal, G., \& Sirris, S. (2019). Values as vessels of religion? The role of values in everyday work at faith-based organizations. Diaconia, 10(1), 27-49. https://doi.org/10.13109/diac.2019.10.1.27

Bech, P., Olsen, L. R., Kjoller, M., \& Rasmussen, N. K. (2003). Measuring well-being rather than the absence of distress symptoms: A comparison of the SF-36 Mental Health subscale and the WHO-Five well-being scale. International journal of methods in psychiatric research, 12(2), 85-91. doi: 10.1002/mpr.145 
Brubaker, P. J., \& Haigh, M. M. (2017). The religious Facebook experience: Uses and gratifications of faith-based content. Social Media+ Society, 3(2), 2056305117703723.

Buckley, D. T., Gainous, J., \& Wagner, K. M. (2021). Is religion the opiate of the digital masses? Religious authority, social media, and protest. Information, Communication \& Society, 117. doi: 10.1080/1369118X.2021.1971279

Bullik, R., \& Stacke, T. (2018). "And so I have the chance to help people. And that makes me happy."-Altruistic Care for Fellow Refugees and Inter-Religious Appreciation-Henry G. In H. Streib \& C. Klein (Eds.), Xenosophia and religion. Biographical and statistical paths for a culture of welcome (pp. 347-366). Springer. DOI: 10.1007/978-3-319-745640_14

Damgaci, F., \& Aydin, H. (2018). What we can learn about multicultural education from social media. EURASIA Journal of Mathematics, Science and Technology Education, 14(3), 797810. doi:10.12973/ejmste/80945

Eginli, A. T., \& Tas, N. O. (2018). Interpersonal communication in social networking sites: An investigation in the framework of uses and gratification theory. Online Journal of Communication and Media Technologies, 8(2), 81-104. https://doi.org/10.12973/ojcmt/2355

Ellison, N. B., Steinfield, C., \& Lampe, C. (2007). The benefits of Facebook "friends:" Social capital and college students' use of online social network sites. Journal of ComputerMediated Communication, 12(4), 1143-1168. https://doi.org/10.1111/j.10836101.2007.00367.x

Fauzi, R. A., \& Asri, Y. (2021). Barriers and solutions in online learning during the Covid-19 pandemic, Indonesian language education students at the Riau Islamic University. [Paper presentaton]. The Ninth International Conference on Language and Arts (ICLA 2020). https://www.atlantis-press.com/proceedings/icla-20/125954660

Fornell, C., \& Larcker, D. F. (1981). Structural equation models with unobservable variables and measurement error: Algebra and statistics. Journal of Marketing Research, 18(1), 382-388. https://doi.org/10.1177/002224378101800104

Fortuin, N. P. (2021). Religion, health and well-being in later life: Storying our lives in the face of death. NTT Journal for Theology and the Study of Religion, 75(1), 95-119. https://doi.org/10.5117/NTT2021.1.006.FORT

Goatley, D. E. (2020). Ministering at the margins in a time of pandemic: Insights from the pilgrimage of justice and peace. The Ecumenical Review, 72(4), 538-552. doi/epdf/10.1111/erev.12547

Hair, J. F., Black, W. C., Babin, B. J., \& Anderson, R. E. (2010). Multivariate data analysis - A global perspective ( $7^{\text {th }}$ ed.). Pearson Prentice Hall.

Henseler, J., Ringle, C. M., \& Sarstedt, M. (2015). A new criterion for assessing discriminant validity in variance-based structural equation modeling. Journal of the Academy of Marketing Science, 43(1), 115-135. doi: 10.1007/s11747-014-0403-8

Henseler, J., Ringle, C. M., \& Sinkovics, R. R. (2009). The use of partial least squares path modeling in international marketing. In R.R. Sinkovics \& P.N. Ghauri, (Eds), New challenges to international marketing (pp. 277-319). Emerald Group Publishing Limited. https://doi.org/10.1108/S1474-7979(2009)0000020014 
Howe, P. D., \& Parker, A. (2014). Disability as a path to spiritual enlightenment: An ethnographic account of the significance of religion in paralympic sport. Journal of Disability \& Religion, 18(1), 8-23. https://doi.org/10.1080/15228967.2014.868988

Huda, M., \& Nur, I. (2021). Islam, culture, and social media: A study on the culture of the social media usage in the Covid-19 pandemic era. The Journal of Society and Media, 5(2), 347361. https://journal.unesa.ac.id/index.php/jsm/index

Khan, M. L. (2017). Social media engagement: What motivates user participation and consumption on YouTube? Computers in Human Behavior, 66, 236-247. https://doi.org/10.1016/j.chb.2016.09.024

Latepo, I., Suharto, S., \& Nurdin, N. (2021). Understanding Muslim preaching students' use of social media. International Journal of International Relations, Media and Mass Communication Studies, 7(1), 52-66. https://ssrn.com/abstract=3856469

Ledbetter, A. M., Mazer, J. P., DeGroot, J. M., Meyer, K. R., Mao, Y., \& Swafford, B. (2011). Attitudes toward online social connection and self-disclosure as predictors of Facebook communication and relational closeness. Communication Research, 38(1), 27-53. https://doi.org/10.1177/0093650210365537

Lloyd, A. (2014). Social media, help or hindrance: What role does social media play in young people's mental health. Psychiatria Danubina, 26(Suppl 1), 340-346. PMID: 25413562

Mansoor, M. (2021). Citizens' trust in government as a function of good governance and government agency's provision of quality information on social media during COVID-19. Government Information Quarterly, 38(4), 101597. doi: 10.1016/j.giq.2021.101597

Mansoor, M., \& Noor, U. (2019). Determinants of green purchase intentions: Positive word of mouth as moderator. Journal of Business \& Economics, 11(2), 143-160. http://journals.au.edu.pk/ojs/index.php/jbe/issue/view/24/119

Mansoor, M., \& Paul, J. (2021). Consumers' choice behavior: An interactive effect of expected eudaimonic well-being and green altruism. Business Strategy and the Environment, 1-16. https://doi.org/10.1002/bse.2876

Morgan, H. (2019). Response to 'Psychological individuation and spiritual enlightenment: some comparisons and points of contact' by Murray Stein. Journal of Analytical Psychology, 64(1), 23-27. https://doi.org/10.1111/1468-5922.12463

Mustapa, M. C., Subhi, N., Ibrahim, F., \& Saleem, M. (2020). Religious knowledge mediates between the knowledge about reproductive health and self-esteem of Malaysian adolescents. Journal of Islamic Thought and Civilization, 10(2). https://doi.org/10.32350/jitc.102

Noor, U., Mansoor, M., \& Rabbani, S. (2021). Brand hate and retaliation in Muslim consumers: does offensive advertising matter? Journal of Islamic Marketing, Vol. ahead-of-print (No. ahead-of-print). https://doi.org/10.1108/JIMA-10-2020-0316

Papacharissi, Z., \& Mendelson, A. (2011). Toward a new(er) sociability: Uses, gratifications, and social capital on Facebook. In S. Papathanassopoulos (Ed.), Media perspectives for the 21st century (pp. 212-230). Routledge. eBook ISBN: 9780203834077

Radstake, J. (2021). Serving all people: Pentecostal experiences in ministering to people with IDD in Ontario. Journal of Disability \& Religion, 25(2), 83-109. https://doi.org/10.1080/23312521.2020.1776666

Samad, S., Nilashi, M., \& Ibrahim, O. (2019). The impact of social networking sites on students' social well-being and academic performance. Education and Information Technologies, 24(3), 2081-2094. https://doi.org/10.1007/s10639-019-09867-6 
Sarstedt, M., Ringle, C. M., \& Hair, J. F. (2017). Partial least squares structural equation modeling. Handbook of market research, 26(1), 1-40. https://doi.org/10.1007/978-3-319-055428_15-1

Siles, I., Guevara, E., Tristán-Jiménez, L., \& Carazo, C. (2021). Populism, religion, and social media in Central America. The International Journal of Press/Politics. [Online first]. https://doi.org/10.1177/19401612211032884

Stein, M. (2019). Psychological individuation and spiritual enlightenment: Some comparisons and points of contact. Journal of Analytical Psychology, 64(1), 622. https://doi.org/10.1111/1468-5922.12462

Stollfub, S. (2020). Communitainment on Instagram: Fitness content and community-driven communication as social media entertainment. SAGE Open, 10(2). doi.org//10.1177/2158244020919535

Sujarwoto, Saputri, R. A. M., \& Yumarni, T. (2021). Social media addiction and mental health among university students during the COVID-19 pandemic in Indonesia. International Journal of Mental Health and Addiction. [Online]. https://doi.org/10.1007/s11469-02100582-3

Syarif, S. (2020). Building plurality and unity for various religions in the digital era: Establishing Islamic values for Indonesian students. Journal of Social Studies Education Research, 11(2), 111-119. Retrieved November 25, 2021, from https://www.learntechlib. org/p/217571/

Tanta, I., Mihovilović, M., \& Sablić, Z. (2014). Uses and gratification theory-why adolescents use Facebook? Medijska istraživanja: Znanstveno-stručni časopis za novinarstvo i medije, 20(2), 85-111. https://hrcak.srce.hr/133809

Tsay-Vogel, M. (2016). Me versus them: Third-person effects among Facebook users. New Media \& Society, 18(9), 1956-1972. https://doi.org/10.1177/1461444815573476

Tsuria, R., \& Yadlin-Segal, A. (2021). Digital religion and global media: Flows, communities, and radicalizations. In S.J. Ward (Ed.) Handbook of global media ethics (pp. 157-175). Springer. DOI: 10.1007/978-3-319-32103-5_10

Wang, Y., \& Qiao, F. (2020). The symbolic meaning of luxury-lite fashion brands among younger Chinese consumers. Journal of Fashion Marketing and Management, 24(1), 83-98. https://doi.org/10.1108/JFMM-09-2019-0204

Williams, R. H. (1996). Religion as political resource: Culture or ideology? Journal for the Scientific Study of Religion, 35(4), 368-378. https://doi.org/10.2307/1386412

Willis, R., Zaidi, A., Balouch, S., \& Farina, N. (2020). Experiences of people with dementia in Pakistan: Help-seeking, understanding, stigma, and religion. The Gerontologist, 60(1), 145-154. https://doi.org/10.1093/geront/gny143

Wilt, J. A., Stauner, N., \& Exline, J. J. (2017). Religion, spirituality, and well-being. In J. E. Maddux (Ed.) Subjective well-being and life satisfaction (pp. 337-354). Routledge. Ebook ISBAN $=9781351231879$

Yoo, J., \& You, S. (2021). Ministerial satisfaction and spiritual well-being among women ministering in Korean Baptist churches. Current Psychology, 40(3), 1194-1202. https://doi.org/10.1007/s12144-018-0039-9 


\section{Notes on Contributors}

Khairil Anwar currently is a lecturer of Islamic Thought and Rector of Institut Agama Islam Negeri Palangka Raya, Central Kalimantan, Indonesia. He graduated his bachelor's Study of Islamic Education at Faculty of Tarbiyah IAIN Sunan Ampel Malang (1989); Master of Islamic Thought (Islamic Studies) at IAIN Syarif Hidayatullah Jakarta (1994); Doctoral Studies of Islamic Thought (Islamic Studies) at UIN Syarif Hidayatullah Jakarta (2007). He has published some articles both national and international level. His research focus is Islamic studies with concentration in Islamic thought. ORCID ID: https://orcid.org/0000-0002-5392-0623.

Abdul Mujib is a Professor at Universitas Islam Negeri (UIN) Syarif Hidayatullah Jakarta in the field of Islamic Psychology and also at Universitas Al-Azhar in Indonesia. In 2009-2014, he was the Head of the Psychology Service Center of the Faculty of Psychology, UIN Jakarta and in 2013-2014, he was the Chair of the Psychology Science Masters Study Program, as well as the Dean of the Psychology Faculty of UIN Syarif Hidayatullah Jakarta for the 2014-2015 and 20152019 periods. Doctoral education in Islamic Studies from UIN Syarif Hidayatullah Jakarta in 2005, and has two Masters degrees each from UIN Imam Bonjol and Universitas Persada Indonesia. an Indonesian academic. Email: abdul.mujib@uinjkt.ac.id ORCID ID: https://orcid.org/0000-00023819-3763). 